H. D. Barrs' review of methods for determining tissue water deficit which is probably the most comprehensive and authoritative account of its kind in the current literature.

Volume two commences with a chapter on water consumption by agricultural plants, outlining the long history of the subject and dealing with evapotranspiration in different climates and with different crops (M. E. Jensen). Water consumption by forests is discussed by A. J. Rutter in a chapter which shows the tremendous progress in this difficult field during the past two decades.

A. S. Craft's review of the effects of water deficit on physiological processes is followed by more detailed accounts of its influence on the growth of herbaceous plants (C. T. Gates) and trees (R. Zahner). These chapters give a useful summary of the present state of knowledge, and the section on tree growth includes information which may be new to many physiologists. The final chapter by $P$. W. Talboys on water deficit in vascular disease also breaks new ground for many readers.

I have few serious criticisms of these books, most of the authors having contributed reviews which will remain sources of reference for some years to come. It is perhaps unfortunate that the section on tissue water deficit methodology could not have been accompanied by an equivalently comprehensive survey of soil water deficit methodology. This was briefly reviewed in Gardner's chapter, but for the methods readers are largely referred to another publication. Another very minor eriticism is the lack of eross-references between chapters, but this is offset by otherwise excellent indexing and self-explanatory tables of contents at the beginning of each volume and the head of each chapter.

The editor and publishers must be congratulated on their achievement, but why must these books be so expensive that most of us will take them only from library shelves?

J. R. ETHERINGTON

\section{STOCKS AND STRAINS}

\section{Experiments in Microbial Genetics}

Edited by R. C. Clowes and W. Hayes. Pp. xii +244. (Blackwell (Scientific): Oxford and Edinburgh, 1968.) $42 s$.

ANyone who has to prepare practical classes in microbial genetics will bless this book, for here are thirty-seven classical experiments, all set out and ready to be done. Mutation, transformation, DNA-RNA hybridization, biochemical geneties, virulent and temperate phage, plasmids, conjugation and Aspergillus are all covered. Each experiment has subheadings "requirements", "method" and "conclusions" with enough references to link it to the literature. But what distinguishes this book as a laboratory guide is the degree of detail provided by the seven authors. Not only are you told how many ml. of this or $\mathrm{mg}$ of that to have ready but, as well as details of the strains and their stock numbers, there is an international registry of laboratories ready to provide the right cultures and phages and a directory of laboratory suppliers. Like a good cookery book-which this somewhat resembles, with its bright cardboard covers and white double-spiral binding-this leaves nothing to chance. It would take real perversity not to bring off these experiments as successfully as the students on the courses run by the MRC Microbial Genetics Research Unit where all these details were first worked out. Students apart, many practising geneticists will find a mass of useful information here, not least the long pedigrees of K12 mutants which, curiously enough, include almost everything but the source of K12 itself (for this, see Nature, 217, 1000; 1968). All in all, this compendium of techniques will be indispensable to everyone working in the field.

G. G. Meynell

\section{Obituaries}

\section{Dr G. Francis}

Dr Gordon Francis, group leader at the Culham Laboratory, died at his home in Abingdon on Saturday, January 4 , at the age of 44 .

After wartime experience at the Admiralty Signals Establishment, Francis took a first in physics at Swansea. From 1948-58 he worked at the Clarendon Laboratory, Oxford, studying high frequency electrodeless discharges, first as a pupil of and later in collaboration with Dr A. von Engel. Francis joined Harwell in 1958 and from then until his death he worked on plasma physics problems connected with the Atomic Energy Authority's programme on controlled thermonuclear reactions. He moved with his group to the Culham site in 1962 .

Francis showed his experimental skill when he made the first measurements of the discharge current during the breakdown phase of a high frequency discharge. In 1956 he wrote a classic review of the glow discharge, and his book Ionization Phenomena in Gases (1960) is widely used. During his time with the Atomic Energy Authority, his chief interest was in the containment of hot plasmas by magnetic mirror systems. By 1964 he and his group were able to report results which showed clearly the increased stability of systems in which the magnetic field strength increases in all directions away from the plasma. This confirmed earlier work by the Soviet physicist, M. S. Ioffe, using very different methods of plasma production. Francis and his colleagues then built a new apparatus with the aim of increasing the ratio of the energy density in the plasma to that in the magnetic field. This experiment is still unfinished, but in his last paper Francis and his colleagues described preliminary measurements showing that a much higher plasma pressure had indeed been obtained without any apparent loss of stability. During this time, Francis's other research included pioneer work on radiofrequeney confinement of plasma and on plasmas produced by the action of laser light on solid hydrogen particles.

Francis's work, both on gas discharges and in plasma physies, was internationally recognized and he became particularly well known for the clarity of his lectures. He played a key part in the production of the film "Power from Fusion", parts I and II, and also took part in television and radio programmes.

\section{Mr H. Gilbert-Carter}

Humphrey Gilbert-Carter, director of the University Botanic Garden, Cambridge, from 1921 to 1950, died on January 4 at his home in Dawlish, Devon, at the age of 84 . After gaining a medical degree at the University of Edinburgh, Gilbert-Carter went to Trinity College, Cambridge, in 1909 to work as an advanced student in the Botany School under C. E. Moss, who was at that time one of the leading teachers in the new science of plant ecology. From these early days, he showed great interest in the work of continental botanists; travelling widely as a student, he developed a life-long affection for north-west Europe and Denmark in particular, and a deep knowledge of the important contributions being made by systematists of the Englerian school and ecologists such as Warming and Raunkiaer. (His Genera of British Plants (1913) introduced British botanists to the Englerian system, and his excellent translation of Raunkiaer's Plant Life Frorms (1937) brought to a much wider audience 